\title{
Huge Pancreatic Acinar Cell Carcinoma with High Levels of AFP and Fucosylated AFP (AFP-L3)
}

\author{
Atsushi Hiraoka ${ }^{1}$, Hiromasa Nakahara ${ }^{1,2}$, Hideki Kawasaki ${ }^{3}$, Yuko Shimizu ${ }^{1}$, Satoshi Hidaka ${ }^{1}$, \\ Yusuke Imai ${ }^{1}$, Hiroki Utsunomiya ${ }^{1}$, Haruka Tatsukawa ${ }^{1}$, Nayu Tazuya ${ }^{1}$, Hiroka Yamago ${ }^{1}$, \\ Nobukazu Yorimitsu ${ }^{1}$, Tetsuya Tanihira ${ }^{1}$, Aki Hasebe ${ }^{1}$, Yasunao Miyamoto ${ }^{1}$, \\ Tomoyuki Ninomiya ${ }^{1}$, Masanori Abe ${ }^{4}$, Yoichi Hiasa ${ }^{4}$, Bunzo Matsuura ${ }^{4}$, \\ Morikazu Onji ${ }^{4}$ and Kojiro Michitaka ${ }^{1}$
}

\begin{abstract}
A 25-year-old Japanese woman with a large abdominal tumor (10 cm in diameter) and high level of serum alpha-fetoprotein (AFP, 1,222.4 ng/mL) was introduced and admitted to our hospital in January 2011. Preoperative imaging modalities could not identify the tumor origin. There was no chronic hepatic viral disease, however, the elevated level of fucosylated AFP (87.8\%) and connection with the left hepatic lobe led us to diagnose the tumor as a hepatocellular carcinoma. Surgical resection was performed in February. Histological findings revealed a pancreatic acinar cell carcinoma (ACC). Herein, we provide details of this difficulty to diagnose a case of ACC.
\end{abstract}

Key words: pancreatic neoplasm, acinar cell carcinoma, AFP, AFP-L3

(Intern Med 51: 1341-1349, 2012)

(DOI: 10.2169/internalmedicine.51.6536)

\section{Introduction}

Serum alpha-fetoprotein (AFP) and fucosylated AFP (AFP-L3) are known as tumor markers of hepatocellular carcinoma (HCC) $(1,2)$. Only a small number of pancreatic acinar cell carcinoma (ACC) cases with elevation of AFP have been reported in literature (Table 1) (3-28). Moreover, only a small number of reports have documented lectin fractionation of AFP in $\operatorname{ACC}(8,17,21)$. We present a case of large pancreatic ACC accompanied by high levels of AFP and AFP-L3, which was difficult to diagnose prior to surgery.

\section{Case Report}

A 25-year-old Japanese woman with a large abdominal tumor and high level of serum AFP $(1,222.4 \mathrm{ng} / \mathrm{mL})$ was introduced to our hospital in January 2011 for further exami- nations. When she bruised her abdomen in skiing and abdominal computed tomography (CT) was performed for the pain. A large abdominal tumor was found incidentally. Dynamic CT revealed a huge hypervascular abdominal tumor with central necrosis without other tumors or metastasis (Fig. 1). Abdominal ultrasonography (US) showed a hypoechoic tumor $10 \mathrm{~cm}$ in diameter with connection to the left hepatic lobe, stomach, and pancreas (Fig. 2a). We considered that the mass originated from the left hepatic lobe. Laboratory data on admission are presented in Table 2.

The serum levels of AFP and AFP-L3 were 2,550.8 ng/ $\mathrm{mL}$ and $87.8 \%$, respectively. Neither markers of viral hepatitis nor elevated serum levels of carcinoembryonic antigen (CEA, $2.0 \mathrm{ng} / \mathrm{mL}$ ) or carbohydrate antigen 19-9 (CA19-9, $17.7 \mathrm{U} / \mathrm{mL})$, DUPAN-2 (66 U/mL), or Span-1 (10.8 U/mL) were detected (Table 2). ${ }^{18} \mathrm{~F}$-fluorodeoxy glucose positron emission tomography (FDG-PET)/CT showed a high uptake of ${ }^{18} \mathrm{~F}$-fluorodeoxy glucose (max-standardized uptake value,

\footnotetext{
${ }^{1}$ Gastroenterology Center, Ehime Prefectural Central Hospital, Japan, ${ }^{2}$ Department of Internal Medicine, Matsuyama Shimin Hospital, Japan, ${ }^{3}$ Department of Surgery, Ehime Prefectural Central Hospital, Japan and ${ }^{4}$ Department of Gastroenterology and Metabology, Ehime University Graduate School of Medicine, Japan

Received for publication September 10, 2011; Accepted for publication January 6, 2012

Correspondence to Dr. Atsushi Hiraoka, hirage@m.ehime-u.ac.jp
} 
Table 1. Reported Cases of Alpha-fetoprotein Producing Pancreatic Acinar Cell Carcinoma

\begin{tabular}{|c|c|c|c|c|c|c|c|c|c|c|c|}
\hline $\begin{array}{l}\text { Auth } \\
\text { or }\end{array}$ & year & $\begin{array}{l}\text { Age } \\
\text { (ye } \\
\text { ars) }\end{array}$ & sex & $\begin{array}{l}\text { Size } \\
(\mathrm{cm})\end{array}$ & Symptoms & $\begin{array}{l}\text { Pre-operative } \\
\text { (pre-autopsy) } \\
\text { diagnosis }\end{array}$ & $\begin{array}{l}\text { Therapy } \\
\text { (anticancer } \\
\text { drug) }\end{array}$ & $\begin{array}{l}\text { Location of tumor } \\
\text { (metastasis) }\end{array}$ & $\begin{array}{l}\text { AFP } \\
(\mathrm{ng} / \mathrm{m} \\
\mathrm{L})\end{array}$ & $\begin{array}{l}\text { AFP-L3 } \\
(\%)\end{array}$ & $\begin{array}{l}\text { Prognosis } \\
\text { (observation } \\
\text { period) }\end{array}$ \\
\hline Ono & 1984 & 69 & $M$ & 6.5 & $\begin{array}{l}\text { Right upper } \\
\text { quadrant pain } \\
\text { and discomfort }\end{array}$ & $\begin{array}{l}\text { Duodenal } \\
\text { tumor }\end{array}$ & Resection & $\begin{array}{l}\text { Pancreas head (with } \\
\text { dissemination to the } \\
\text { peritoneum) }\end{array}$ & 65,000 & NA & Died (3M) \\
\hline Inui & 1984 & 30 & $\mathrm{~F}$ & NA & $\begin{array}{l}\text { Epigastralgia } \\
\text { and cough }\end{array}$ & $\begin{array}{l}\text { Pancreas } \\
\text { tumor }\end{array}$ & $\begin{array}{l}\text { Chemotherapy } \\
\text { (5-FU, MMC } \\
\text { and OK432) }\end{array}$ & $\begin{array}{l}\text { Pancreas head (with } \\
\text { pulmonary and } \\
\text { lymph node } \\
\text { metastases) }\end{array}$ & 1,700 & NA & Died (7M) \\
\hline $\begin{array}{l}\text { Kikuc } \\
\text { hi }\end{array}$ & 1985 & 38 & M & NA & $\begin{array}{l}\text { Lumbago and } \\
\text { diarrhea }\end{array}$ & $\begin{array}{l}\text { Pancreatic } \\
\text { cancer }\end{array}$ & $\begin{array}{l}\text { Chemotherapy } \\
\text { (NA) }\end{array}$ & $\begin{array}{l}\text { Pancreas body and } \\
\text { head (with } \\
\text { peritoneal } \\
\text { metastasis) }\end{array}$ & 26,800 & NA & Died (1.5M) \\
\hline $\begin{array}{l}\text { Kikuc } \\
\text { hi }\end{array}$ & 1985 & 60 & M & NA & Melena & NA & NA & $\begin{array}{l}\text { NA (with hepatic } \\
\text { metastasis) }\end{array}$ & 200 & NA & Died (16M) \\
\hline $\begin{array}{l}\text { Yajim } \\
\text { a }\end{array}$ & 1987 & 38 & $M$ & NA & $\begin{array}{l}\text { Epigastralgia, } \\
\text { back pain, } \\
\text { diarrhea and } \\
\text { body weight } \\
\text { loss }\end{array}$ & $\begin{array}{l}\text { Pancreatic } \\
\text { cancer }\end{array}$ & $\begin{array}{l}\text { Chemotherapy } \\
\text { (5-FU, MMC } \\
\text { and urokinase) }\end{array}$ & $\begin{array}{l}\text { Pancreas body and } \\
\text { tail (lymph node } \\
\text { metastasis) }\end{array}$ & 800 & NA & Died (15M) \\
\hline $\begin{array}{l}\text { Takez } \\
\text { aki }\end{array}$ & 1988 & 77 & M & 14.0 & $\begin{array}{l}\text { Appetite loss } \\
\text { and general } \\
\text { fatigue }\end{array}$ & $\begin{array}{l}\text { Pancreas } \\
\text { tumor }\end{array}$ & UFT & $\begin{array}{l}\text { Pancreas body (with } \\
\text { hepatic metastasis) }\end{array}$ & 7,756 & NA & Died (2M) \\
\hline $\begin{array}{l}\text { Noji } \\
\text { ma }\end{array}$ & 1992 & 57 & M & 6.5 & $\begin{array}{l}\text { Epigastic pain } \\
\text { and vomiting }\end{array}$ & $\begin{array}{l}\text { Pancreas } \\
\text { tumor }\end{array}$ & $\begin{array}{l}\text { Resection and } \\
\text { chemotherapy } \\
\text { (NA) }\end{array}$ & $\begin{array}{l}\text { Pancreas tail (with } \\
\text { hepatic metastasis) }\end{array}$ & 1,500 & 58 & Alive (32M) \\
\hline $\begin{array}{l}\text { Kawa } \\
\text { moto }\end{array}$ & 1992 & 77 & $\mathrm{~F}$ & 6.0 & Epigastric pain & $\begin{array}{l}\text { Pancreas } \\
\text { tumor }\end{array}$ & Resection & Pancreas body & 5,790 & NA & Alive (2M) \\
\hline Itoh & 1992 & 60 & M & NA & $\begin{array}{l}\text { None (pointed } \\
\text { out by a } \\
\text { routine health } \\
\text { check) }\end{array}$ & $\begin{array}{l}\text { Pancreatic } \\
\text { cancer }\end{array}$ & Resection & $\begin{array}{l}\text { Pancreas body and } \\
\text { tail }\end{array}$ & 415 & NA & Alive (24M) \\
\hline $\begin{array}{l}\text { Ishiz } \\
\text { aki }\end{array}$ & 1995 & 57 & M & 3.6 & $\begin{array}{l}\text { Epigastralgia } \\
\text { with vomiting }\end{array}$ & $\begin{array}{l}\text { Pancreatic } \\
\text { cystadenocarci } \\
\text { noma }\end{array}$ & Resection & $\begin{array}{l}\text { Pancreas tail (with } \\
\text { hepatic metastasis) }\end{array}$ & 1,500 & NA & Died (37M) \\
\hline $\begin{array}{l}\text { Oka } \\
\text { moto }\end{array}$ & 1995 & 18 & M & 8.0 & Icterus & $\begin{array}{l}\text { Pancreas } \\
\text { tumor or } \\
\text { malignant } \\
\text { lymphoma }\end{array}$ & Resection & Pancreas head & 11,900 & NA & Alive (8M) \\
\hline Fujiki & 1996 & 41 & $\mathrm{~F}$ & 4.8 & $\begin{array}{l}\text { Epigastralgia } \\
\text { and icterus }\end{array}$ & $\begin{array}{l}\text { Pancreatic } \\
\text { cancer }\end{array}$ & $\begin{array}{l}\text { Chemotherapy } \\
\text { (5-FU, } \\
\text { epirubicin and } \\
\text { MMC) }\end{array}$ & Pancreas body & 23,003 & NA & Died (8M) \\
\hline $\begin{array}{l}\text { Sako } \\
\mathrm{n}\end{array}$ & 1996 & 56 & $M$ & 9.5 & $\begin{array}{l}\text { Epigastralgia } \\
\text { and back pain }\end{array}$ & $\begin{array}{l}\text { Pancreas } \\
\text { tumor }\end{array}$ & Resection & Pancreas tail & 253 & NA & Alive (16M) \\
\hline Morii & 1998 & 47 & M & NA & $\begin{array}{l}\text { Abdominal } \\
\text { fullness and } \\
\text { appetite loss }\end{array}$ & $\begin{array}{l}\text { Pancreatic } \\
\text { cancer }\end{array}$ & $\begin{array}{l}\text { Resection and } \\
\text { chemotherapy } \\
\text { (5-FU, } \\
\text { adriamycin, } \\
\text { MMC) }\end{array}$ & $\begin{array}{l}\text { Pancreas tail (with } \\
\text { hepatic and splenic } \\
\text { metastases) }\end{array}$ & 11,550 & NA & Died (10M) \\
\hline $\begin{array}{l}\text { Shina } \\
\text { gawa }\end{array}$ & 1999 & 30 & $\mathrm{~F}$ & 4.0 & $\begin{array}{l}\text { Epigastric } \\
\text { discomfport }\end{array}$ & $\begin{array}{l}\text { Pancreatic } \\
\text { tumor }\end{array}$ & Resection & Pancreas head & 350 & NA & NA \\
\hline $\begin{array}{l}\text { Erigu } \\
\text { chi }\end{array}$ & 2000 & 67 & $M$ & 12.0 & $\begin{array}{l}\text { Severe } \\
\text { epigastralgia }\end{array}$ & $\begin{array}{l}\text { Rupture of } \\
\text { HCC }\end{array}$ & Resection & $\begin{array}{l}\text { Upper abdominal } \\
\text { cavity (=pancreas } \\
\text { body) }\end{array}$ & 125.5 & 1.4 & Alive (6M) \\
\hline Chen & 2001 & 78 & $\mathrm{~F}$ & 12.0 & $\begin{array}{l}\text { Anorexia, } \\
\text { nausea, } \\
\text { vomiting, } \\
\text { epigastralgia } \\
\text { and body } \\
\text { weight loss }\end{array}$ & $\begin{array}{l}\text { Pancreatic } \\
\text { acinar cell } \\
\text { carcinoma (by } \\
\text { a sono-guided } \\
\text { biopsy) }\end{array}$ & $\begin{array}{l}\text { Chemotherapy } \\
\text { (Gemcitabine) }\end{array}$ & Pancreas head & 8,164 & NA & Alive (2M) \\
\hline
\end{tabular}




\begin{tabular}{|c|c|c|c|c|c|c|c|c|c|c|c|}
\hline $\begin{array}{l}\text { Auth } \\
\text { or }\end{array}$ & year & $\begin{array}{l}\text { Age } \\
\text { (ye } \\
\text { ars) }\end{array}$ & sex & $\begin{array}{l}\text { Size } \\
(\mathrm{cm})\end{array}$ & Symptoms & $\begin{array}{l}\text { Pre-operative } \\
\text { (pre-autopsy) } \\
\text { diagnosis }\end{array}$ & $\begin{array}{l}\text { Therapy } \\
\text { (anticancer } \\
\text { drug) }\end{array}$ & $\begin{array}{l}\text { Location of tumor } \\
\text { (metastasis) }\end{array}$ & $\begin{array}{l}\text { AFP } \\
(\mathrm{ng} / \mathrm{m} \\
\mathrm{L})\end{array}$ & $\begin{array}{l}\text { AFP-L3 } \\
(\%)\end{array}$ & $\begin{array}{l}\text { Prognosis } \\
\text { (observation } \\
\text { period) }\end{array}$ \\
\hline $\begin{array}{l}\text { Akas } \\
\text { hi }\end{array}$ & 2001 & 50 & M & 10.0 & $\begin{array}{l}\text { Appetite loss } \\
\text { and back pain }\end{array}$ & $\begin{array}{l}\text { Pancreatic } \\
\text { cancer }\end{array}$ & $\begin{array}{l}\text { Chemotherapy } \\
\text { (5-FU and } \\
\text { CDDP) }\end{array}$ & $\begin{array}{l}\text { Pancreas body (with } \\
\text { pulmonary and } \\
\text { lympho node } \\
\text { metastases) }\end{array}$ & 62 & NA & Died (13M) \\
\hline $\begin{array}{l}\text { Yama } \\
\text { uchi }\end{array}$ & 2001 & 63 & $F$ & 5.0 & $\begin{array}{l}\text { Epigastralgia, } \\
\text { icterus }\end{array}$ & $\begin{array}{l}\text { Pancreatic } \\
\text { acinar cell } \\
\text { carcinoma } \\
\text { (biopsy against } \\
\text { hepatic } \\
\text { metastasis) }\end{array}$ & $\begin{array}{l}\text { Chemotherapy } \\
\text { (5-FU and } \\
\text { Carboplation) }\end{array}$ & $\begin{array}{l}\text { Pancreas head (with } \\
\text { hepatic metastasis) }\end{array}$ & 2,490 & NA & Died $(8 \mathrm{M})$ \\
\hline Mori & 2004 & 33 & M & 8.0 & $\begin{array}{l}\text { Epicgastralgia } \\
\text { and back pain }\end{array}$ & $\begin{array}{l}\text { Pancreatic } \\
\text { acinar cell } \\
\text { carcinoma (by } \\
\text { EUS-FNA) }\end{array}$ & $\begin{array}{l}\text { Chemotherapy } \\
\text { (5-FU and } \\
\text { CDDP) }\end{array}$ & $\begin{array}{l}\text { Pancreas head and } \\
\text { body (with invasion } \\
\text { to portal vein and } \\
\text { hepatic artery) }\end{array}$ & 12,886 & 38.1 & Alive (11M) \\
\hline $\begin{array}{l}\text { Mishi } \\
\text { ma }\end{array}$ & 2005 & 49 & M & 3.0 & $\begin{array}{l}\text { Epigastralgia } \\
\text { and back pain }\end{array}$ & $\begin{array}{l}\text { Pancreatic } \\
\text { cancer }\end{array}$ & $\begin{array}{l}\text { Chemotherapy } \\
\text { (Gemcitabine) }\end{array}$ & Pancreas head & 823 & NA & Died (10M) \\
\hline $\begin{array}{l}\text { Oka } \\
\text { mura }\end{array}$ & 2005 & 60 & M & 3.0 & $\begin{array}{l}\text { Epigastralgia } \\
\text { and sufferd left } \\
\text { backache }\end{array}$ & $\begin{array}{l}\text { Pancreatic islet } \\
\text { cell tumor }\end{array}$ & $\begin{array}{l}\text { Chemotherapy } \\
\text { (NA) }\end{array}$ & $\begin{array}{l}\text { Pancreas tail (with } \\
\text { hepatic and lymph } \\
\text { nodes metastasis) }\end{array}$ & 899 & NA & Died (10M) \\
\hline Lin & 2007 & 47 & M & 2.0 & $\begin{array}{l}\text { None (routine } \\
\text { health } \\
\text { check-up) }\end{array}$ & $\begin{array}{l}\text { Pancreatic } \\
\text { adenocarcinom } \\
\text { a or endocrine } \\
\text { tumor }\end{array}$ & resection & Pancreas tail & $\begin{array}{l}463.69 \\
(\mathrm{HBV} \\
\text { carrier } \\
\text { ) }\end{array}$ & NA & Alive (36M) \\
\hline $\begin{array}{l}\text { Kolb- } \\
\text { van } \\
\text { Harte } \\
n\end{array}$ & 2007 & 77 & M & NA & $\begin{array}{l}\text { Increasing } \\
\text { fatigue and } \\
\text { impaired } \\
\text { appetite }\end{array}$ & $\begin{array}{l}\text { Pancreatic } \\
\text { acinar cell } \\
\text { carcinoma (by } \\
\text { EUS-FNA) }\end{array}$ & $\begin{array}{l}\text { Chemotherapy } \\
\text { (Gemcitabine } \\
\text { and MMC) }\end{array}$ & Pancreas body & $>32,000$ & NA & Died (7M) \\
\hline $\begin{array}{l}\text { Kawa } \\
\text { guchi }\end{array}$ & 2009 & 63 & M & 10.0 & Epigastralgia & $\begin{array}{l}\text { Abdominal } \\
\text { tumor }\end{array}$ & Resection & Left upper abdomen & 871.1 & NA & Alive (6M) \\
\hline Fujii & 2010 & 59 & M & 4.5 & Anemia & $\begin{array}{l}\text { Pancreas } \\
\text { tumor }\end{array}$ & $\begin{array}{l}\text { Resection } \\
\text { [Chemotherap } \\
\text { y (CDDP and } \\
\text { S1) against } \\
\text { recurrence } \\
\text { with hepatic } \\
\text { metastasis] }\end{array}$ & Pancreas head & $\begin{array}{l}8,228 \\
\text { (Data } \\
\text { at } \\
\text { recurre } \\
\text { nce) }\end{array}$ & NA & Died (36M) \\
\hline Lee & 2010 & 48 & $F$ & 1.2 & Chest tightness & $\begin{array}{l}\text { Pancreatic } \\
\text { cancer }\end{array}$ & Resection & Pancreas head & $\begin{array}{l}89.95( \\
\mathrm{U} / \mathrm{L}) \\
\text { (HBV } \\
\text { carrier) }\end{array}$ & NA & Alive (71M) \\
\hline $\begin{array}{l}\text { Prese } \\
\text { nt } \\
\text { case }\end{array}$ & 2011 & 25 & $\mathrm{~F}$ & 10.0 & $\begin{array}{l}\text { None (pain for } \\
\text { a bruise on the } \\
\text { abdomen on } \\
\text { skiing) }\end{array}$ & $\begin{array}{l}\text { Suspected for } \\
\text { HCC }\end{array}$ & $\begin{array}{l}\text { Resection and } \\
\text { chemotherapy } \\
\text { (Gemcitabine) }\end{array}$ & $\begin{array}{l}\text { Upper abdominal } \\
\text { cavity (= pancreas } \\
\text { head) (with hepatic } \\
\text { metastasis) }\end{array}$ & $2,550.8$ & 87.8 & Died (10M) \\
\hline
\end{tabular}

HCC, hepatocellular carcinoma; NA, not available; AFP, alpha-fetoprotein; AFP-L3, fucocylated AFP; EUS-FNA, endoscopic ultrasound with fine needle aspiration; CDDP, cisplatin; 5-FU, 5-fluorouracil; OK432, Picibanil; MMC, mitomycin C; UFT, tegafur - uracil; HBV, hepatitis B virus

8.4) in the tumor and no metastasis (Fig. 2b). A contrastenhanced US (CEUS) examination with Sonazoid (Perflubutane; Daiichi Sankyo, Tokyo, Japan) showed a suspected necrotic area in the center of the tumor and the description was non-vascular. Furthermore, B-mode US did not detect another hepatic tumor other than the main large abdominal mass. In the Kupffer phase of CEUS, a small defect $(0.9 \mathrm{~cm}$ in diameter) was detected in the 5th segment of the liver (Fig. 2c), which was enhanced by re-injection of Sonazoid
(Fig. 2d). Though, pancreas became atrophic and the main pancreatic duct (MPD) appeared to be suspended due to oppression of the tumor, the dilatations of MPD and common bile duct were not revealed by magnetic resonance cholangiopancreatography (MRCP). However, occlusion of the splenic vein was suspected by late phase of dynamic CT. Angiography showed the occlusion of the splenic vein by compression with the tumor and formation of collateral vessels. In spite of the compression with the tumor, the portal 


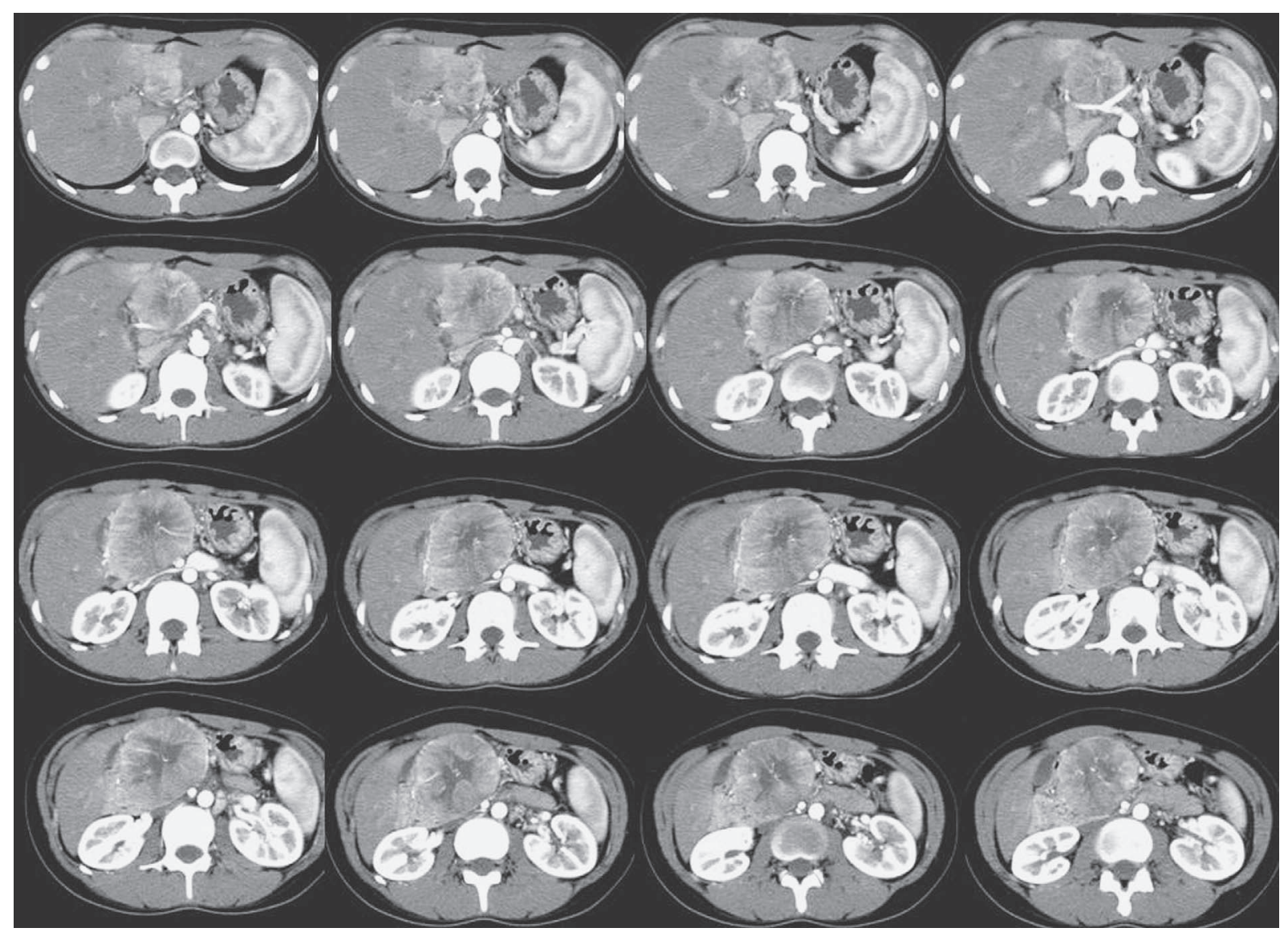

Figure 1. Dynamic computed tomography (CT) image showing a large hypervascular abdominal tumor with central necrosis. There was no hepatic lesion detected by dynamic CT.

vein was intact by portography, and gastroduodenal artery was found to be the main feeder of the tumor (Fig. 3). We made a diagnosis of $\mathrm{HCC}$ and intrahepatic metastasis of HCC based on serological examination results (AFP, AFP-L3), as well as hypervascular findings in dynamic CT and CEUS images.

Surgical resection of the main tumor and small lesion in the 5th segment of the liver was performed in February 2011 (pancreaticoduodenectomy-II A-2, Hr0). The main tumor was located in the pancreas head. Portal vein and common bile duct were oppressed by the tumor. Adhesion between the tumor and splenic vein was observed in macroscopic finding (Fig. 4a-c). The atypical cells with eosinophilic cytoplasm formed microglandular structures as seen by Hematoxylin and Eosin (HE) staining. The large tumor and hepatic tumor were diagnosed as a pancreatic acinar cell carcinoma. Chromogranin was negative by immune staining (Fig. 4f-h). Pathological examinations of the tumors revealed ACC and hepatic metastasis (medullary type, INF $\alpha$, ly1, v1, ne0, mpd-, pCH-, pDU, pS-, pRP-, pPVsp+, pA-, pPLX, pOO-, n(-0/4). pT4N0M1(HEP), pStage IV) (29). Tumor invasion to the splenic vein was proven histologically. Immunostaining for AFP was positive (Fig. 4i). Multiple hepatic metastases and peritoneal dissemination were diagnosed 8 months after resection and she was treated by chemotherapy with Gemcitabine $\left(\right.$ Gemzar $\left.^{\circledR}\right)$. Two months after diagnosis of recurrence, she was died.

\section{Discussion}

Pre-operative diagnosis is difficult in many cases of ACC (30). One case was diagnosed as rupture of HCC (17). In the present case, both AFP and AFP-L3, which is known as a specific tumor marker for $\operatorname{HCC}(1,2)$, were elevated, and elevation of the latter made it difficult to diagnose the huge tumor originating from the pancreas before the operation. Although the positivity rate for AFP is reported to be under $10 \%$ in cases of fibrolamellar carcinoma (31), it must be considered in the differential diagnosis (32) along with ectopic HCC (33) in cases with an abdominal tumor in another organ other than the liver, as in the present case. In 4 cases of past reports, AFP-L3 was examined, and 3 of them showed elevation of AFP-L3. Elevation of AFP-L3 in AFPproducing ACC might not be rare. There were only 4 cases (14.3\%), which were diagnosed as ACC pre-operative or pre-autopsy, in past reports (Table 1).

An ACC is a rare tumor that comprises approximately $1 \%$ of exocrine pancreatic tumors $(34,35)$. Klimstra et al. reported no significant gender differences for affected patients and a poor prognosis, and also estimated that AFP producing ACC tumors were found in $6 \%$ of these cases, with pancreatic ACC found in the head of the pancreas in slightly 


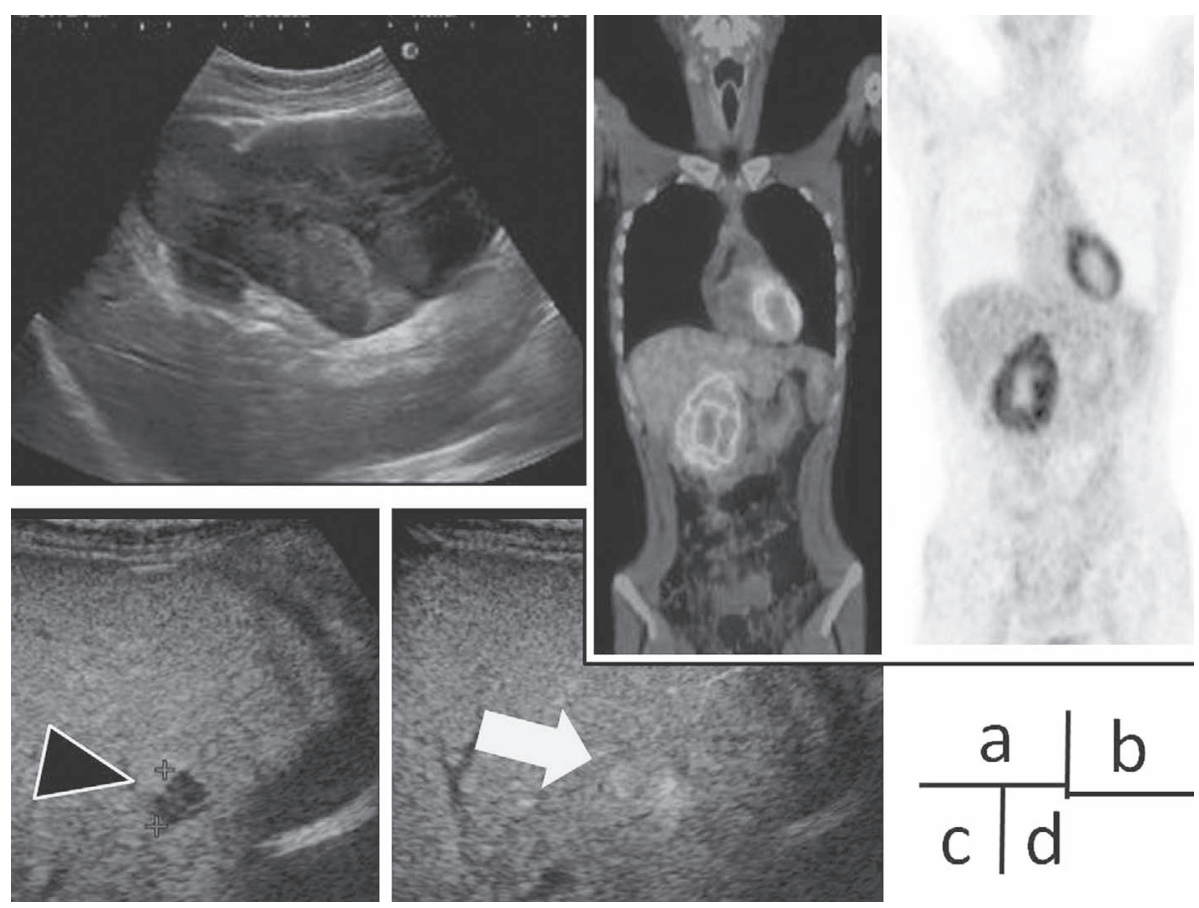

Figure 2. a. The tumor was revealed as a hypoechoic lesion (10 cm in diameter) by abdominal Bmode ultrasonography (US). There was no detection of hepatic tumor by B-mode US. The head of the pancreas and common bile duct could not be revealed because of oppression. The tumor was adjacent to the left hepatic lobe and the body of stomach. b. ${ }^{18} \mathrm{~F}$-fluorodeoxy glucose positron emission tomography (FDG-PET)/CT revealed a high level of uptake of ${ }^{18}$ F-fluorodeoxy glucose (max-standardized uptake value, 8.4) in the tumor and no detection of metastasis. $c$. In the Kupfer phase of contrast-enhanced US, a small defect $(0.9 \mathrm{~cm}$ in diameter) was detected in the 5 th segment of the liver (black arrowhead). d. The defect was enhanced by re-injection of Sonazoid (white arrow).

Table 2. Laboratory Data on Admission

\begin{tabular}{lclllc}
\hline White blood cells & $2,710 / \mathrm{uL}$ & TP & $7.1 \mathrm{~g} / \mathrm{dL}$ & AFP & $2,550.8 \mathrm{ng} / \mathrm{mL}$ \\
Red blood cells & $424 \times 10^{4} / \mu \mathrm{L}$ & Alb & $4.3 \mathrm{~g} / \mathrm{dL}$ & AFP-L3 & $87.8 \%$ \\
Hemoglobin & $12.4 \mathrm{~g} / \mathrm{dL}$ & T-Bil & $0.5 \mathrm{mg} / \mathrm{dL}$ & PIVKA-II & $24 \mathrm{mAU} / \mathrm{L}$ \\
Hematocrit & $37.4 \%$ & AST & $14 \mathrm{IU} / \mathrm{L}$ & CEA & $2.0 \mathrm{ng} / \mathrm{mL}$ \\
Platelets & $16.6 \times 10^{4} / \mu \mathrm{L}$ & ALT & $15 \mathrm{IU} / \mathrm{L}$ & CA19-9 & $17.7 \mathrm{U} / \mathrm{mL}$ \\
Prothrombin time & $86.0 \%$ & ALP & $147 \mathrm{IU} / \mathrm{L}$ & DUPAN-2 & $66 \mathrm{U} / \mathrm{mL}$ \\
& & ChE & $241 \mathrm{IU} / \mathrm{L}$ & Span-1 & $10.8 \mathrm{U} / \mathrm{mL}$ \\
HbA1c & $5.9 \%$ & TTT & $3.6 \mathrm{U}$ & S-IL-2 R & $238 \mathrm{U} / \mathrm{mL}$ \\
FBG & $108 \mathrm{mg} / \mathrm{dL}$ & ZTT & $7.5 \mathrm{U}$ & & \\
ESR & $20 \mathrm{~mm}(1 \mathrm{hr})$. & Amy & $35 \mathrm{IU} / \mathrm{L}$ & HBsAg & $(-)$ \\
& $55 \mathrm{~mm}(2 \mathrm{hr})$. & BUN & $8.6 \mathrm{mg} / \mathrm{dL}$ & HBcAb & $(-)$ \\
& & Cre & $0.61 \mathrm{mg} / \mathrm{dL}$ & Anti-HCV & $(-)$ \\
& & Na & $140 \mathrm{mEq} / \mathrm{L}$ & ANA & $<40$ \\
& & K & $4.5 \mathrm{mEq} / \mathrm{L}$ & AMA(M2) & $<5.0$ \\
& & Cl & $103 \mathrm{mEq} / \mathrm{L}$ & IgG & $1,331 \mathrm{mg} / \mathrm{dL}$ \\
& & & & Ferritin & $25.4 \mathrm{ng} / \mathrm{mL}$ \\
\hline
\end{tabular}

HbA1c, hemoglobin A1c; FBG, fasting blood glucose; ESR, erythrocyte sedimentation rate; PT, prothrombin time; TP, total protein; Alb, albumin; T-Bil, total bilirubin; AST, aspartate aminotransferase; ALT, alanine aminotransferase; ALP, alkaline Phosphatase; ChE, cholinesterase; TTT, thymol turbidity test; ZTT, zinc turbidity test; Amy, amylase; BUN, blood urea nitrogen; Cre, creatinine; Na, sodium; K, potassium; $\mathrm{Cl}$, chlorine; AFP, alpha-fetoprotein; AFP-L3, fucocylated AFP; PIVKA-II, protein induced by vitamin K absence-II; CEA, carcinoembryonic antigen; CA19-9, carbohydrate antigen 19-9; S-IL-2 R, soluble interleukin-2 receptor; HBsAg, hepatitis B surface antigen; HBcAb, hepatitis B core antibody; anti-HCV, hepatitis C virus antibody; ANA, antinuclear antibody ; AMA (M2), antimitochondrial antibody (M2); IgG, immunoglobulin G

more than half (56\%) (36). On the other hand, the 5-year survival rate after resection was described to be favorable $(43.9 \%)$ in the resectable cases (30).
AFP is a tumor marker for HCC. Ishizaki et al. reported that cases of pancreatic ACC with elevated serum AFP are very rare (11), whereas the frequency of pancreatic neo- 


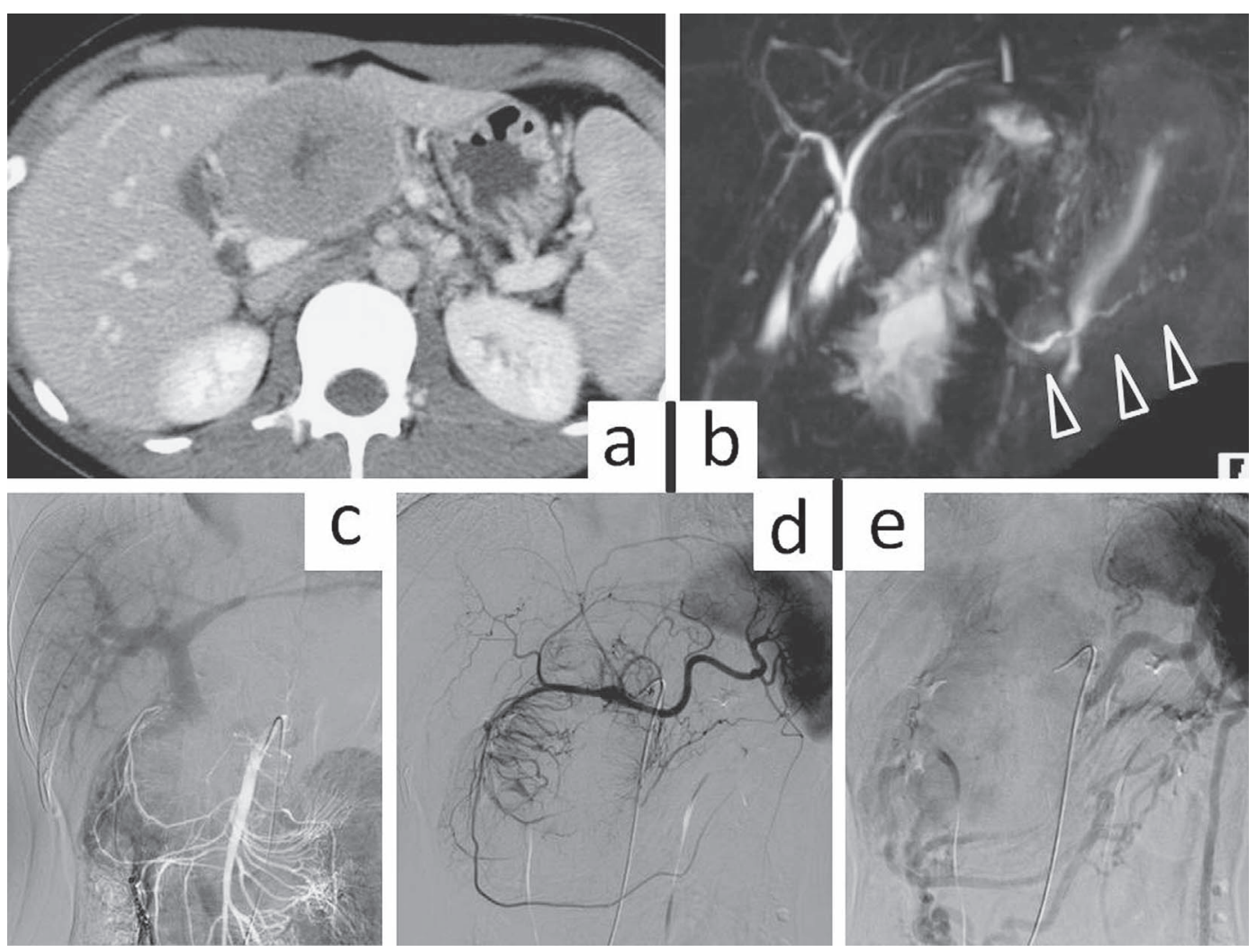

Figure 3. a. In late phase of dynamic CT, occlusion of the splenic vein due to oppression of the tumor was suspected. The portal vein was intact. b. Though, the pancreas became atrophic and the main pancreatic duct (MPD) appeared to be suspended due to oppression of the tumor, the dilatation of MPD was not detected by magnetic resonance cholangiopancreatography (MRCP) (black arrowhead). c. The portal vein was intact by portography. d. Angiography showed gastroduodenal artery was the main feeder of the tumor. e. Occlusion of the splenic vein was caused by compression with the tumor and formation of collateral vessels was seen.

plasms in patients with elevated serum AFP levels is higher in previous reports (37). Other studies also noted that ACCs comprised $27 \%$ of pancreatic neoplasms in cases with elevated serum AFP levels (38). The mechanism of production of AFP without HCC has not been elucidated, though production of AFP by hepatoid differentiation of cancer cells (39-41) and production of AFP by entero-blastic differentiation (42) have been proposed. The reasons for the elevation of AFP-L3 could not be clearly elucidated. It is important to bear in mind that elevation of AFP-L3 could be observed in AFP producing ACC.

Metastasis was not detected by FDG-PET/CT in the present case. Although it is a powerful modality for screening of metastasis, FDG-PET/CT has a limitation for the detection of small metastatic hepatic tumors $(<1 \mathrm{~cm})$ in the liver because of resolution limits (43). CEUS with Sonazoid has been reported as a useful modality for the detection for hepatic malignant tumors (44) and screening of hepatic metastasis (43). Using CEUS with Sonazoid, a small tumor was detected as a defect in the 5th segment of the liver in the Kupffer phase in the present case and enhanced uniformly by re-injection (45). We diagnosed the small tumor as intrahepatic metastasis of HCC prior to resection. Although, distal MPD was revealed without dilatation by MRCP, multi- planar reconstruction images of enhanced CT (MPR-CT) provided more information than magnetic resonance imaging (MRI) and MRCP regarding portal and splenic veins in preoperative studies of the present case. Though, the enhancement pattern of the tumor was similar to HCC, and serum levels of AFP and AFP-L3 were elevated, we should suspect that the origin of the tumor was the pancreas head, because displacement of the bilateral lobes of the liver was observed and the main feeder of the tumor was the gastroduodenal artery. Further examination endoscopic ultrasonography (EUS) should be considered to perform in order to discriminate whether the origin of the tumor was the pancreas or not. Recently, EUS fine needle aspiration (EUS-FNA) has been reported to be an effective modality for the diagnosis of AFP producing ACC $(21,25)$. The elevation of the levels of AFP and AFP-L3 mislead us in the present case. And we suspected an ectopic or fibrolamellar HCC at first, and did not plan to perform EUS-FNA. Following surgical resection, HE staining showed that the atypical cells with eosinophilic cytoplasm formed microglandular structures. It is difficult to obtain stability of immune staining of trypsin, chymotrypsin, lipase, and/or elastase. Though, these immune stainings of trypsin and chymotrypsin were negative in the present pathological findings, pancreatic ductal cancer and neuroen- 

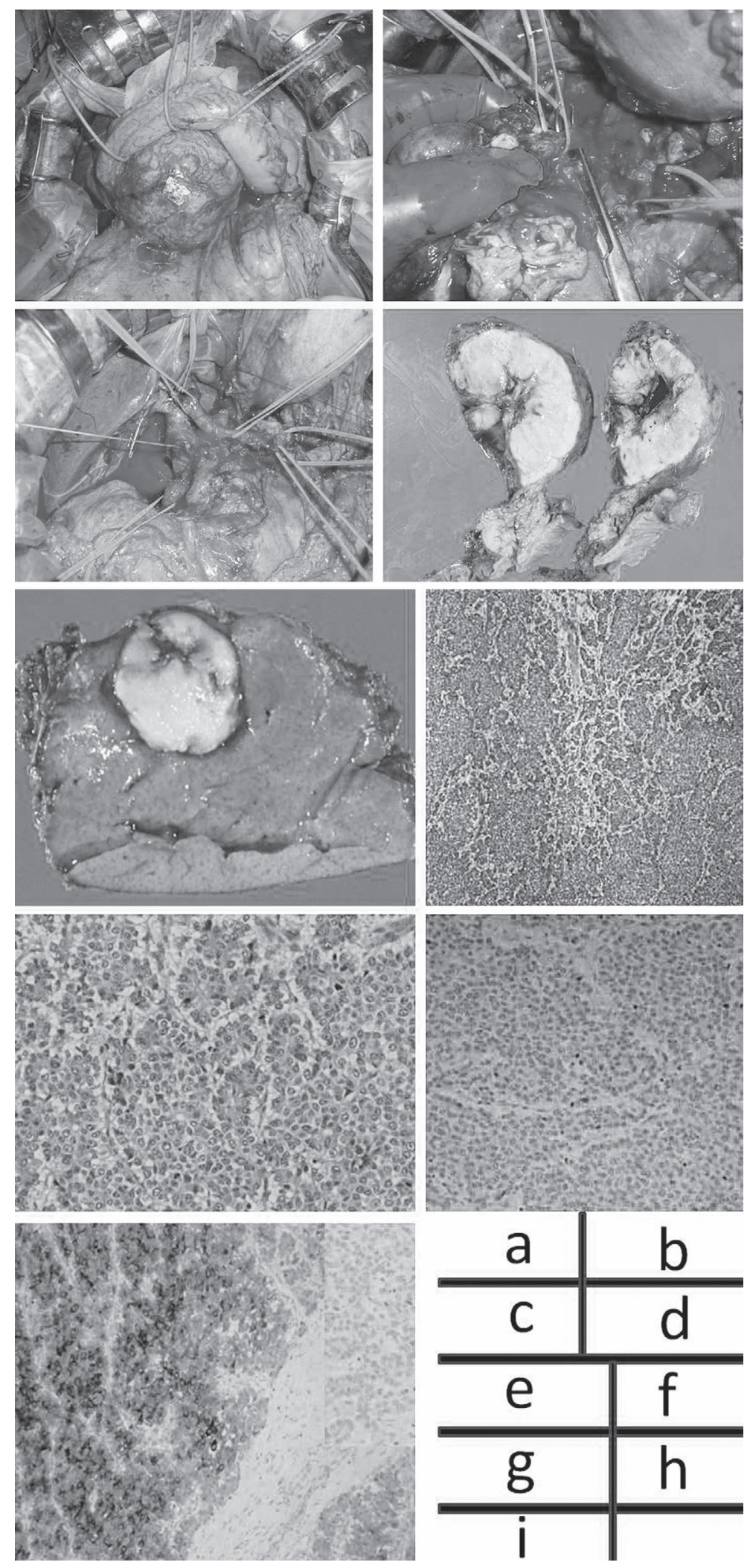

Figure 4. a. Huge tumor was located at the pancreas head. Portal vein and common bile duct were oppressed by the tumor. b. Adhesion between the tumor and splenic vein was observed in macroscopic findings. c. Simultaneously, the splenic vein was resected and portal vein repaired in pancreaticoduodenectomy. $d$. The maximum diameter was enlarged rapidly to $14 \mathrm{~cm}$ in diameter. $\mathrm{e}$. The hepatic tumor (enlarged to $1.5 \mathrm{~cm}$ in diameter) was resected simultaneously. $\mathrm{f}$, g. The atypical cells with eosinophilic cytoplasm formed microglandular structures as seen by Hematoxylin and Eosin staining. The large tumor and hepatic tumor were diagnosed as a pancreatic acinar cell carcinoma. h. Chromogranin was negative by immune staining. i. Alpha-fetoprotein was positive following immune staining. 
docrine tumor were denied, and histological findings led to a final diagnosis of AFP producing ACC.

In the past reports, 1- and 3-year survival rates of the cases that could be treated with resection were approximately 70 and $50 \%$, respectively. However, the prognoses of the cases which were not indicated for surgical resection and treated only with chemotherapy were very poor. One-year survival rate of such cases was approximately 20\%. Establishment of effective methods for preoperative diagnosis and a therapeutic strategy for ACC is needed. No therapeutic strategy except for resection has been established. Accumulation of additional cases is needed to establish strategies for the diagnosis and therapy for ACC, especially those producing AFP.

The authors state that they have no Conflict of Interest (COI).

\section{References}

1. Aoyagi Y, Isemura M, Suzuki Y, et al. Fucosylated alphafetoprotein as marker of early hepatocellular carcinoma. Lancet ii 1353-1354, 1985.

2. Kumada T, Nakano S, Takeda I, et al. Clinical utility of Lens culinaris agglutinin-reactive alpha-fetoprotein in small hepatocellular carcinoma: special reference to imaging diagnosis. J Hepatol 30: 125-130, 1999.

3. Ono J, Sakamoto H, Sakoda K, et al. Acinar cell carcinoma of the pancreas with elevated serum alpha-fetoprotein. Int Surg 69: 361364, 1984.

4. Inui K, Nakae Y, Watanabe K, et al. An autopsy case of acinar cell carcinoma of the pancreas with elevated serum AFP levels. Tan to Sui 5: 783-789, 1984 (in Japanese).

5. Kikuchi Y, Moroboshi T, Kanda M, et al. Acinar cell carcinoma of the pancreas. Report of three cases with immunocytochemical and electronmicroscopical studies. Kan Tan Sui 10: 305-310, 1985 (in Japanese).

6. Yajima T, Hino K, Hunatomi H, et al. A case of alpha-fetoprotein producing acinar cell carcinoma of the pancreas. Shoukakika 6 : 318-324, 1987 (in Japanese, abstract in English).

7. Takezaki E, Takaishi K, Kagawa K, et al. An autopsy case of pancreatic cancer with a tentative diagnosis of hepatocellular carcinoma due to metastatic tumor of the liver and elevated levels of serum AFP. Tan to Sui 9: 1271-1276, 1988 (in Japanese).

8. Nojima T, Kojima T, Kato $H$, Sato $T$, Koito K, Nagashima $K$. Alpha-fetoprotein-producing acinar cell carcinoma of the pancreas. Human Pathol 23: 828-830, 1992.

9. Kawamoto S, Hiraoka T, Kanemitsu K, et al. Alpha-fetoproteinproducing pancreatic cancer-a case report and review of 28 cases. Hepatogastroenterol 39: 1271-1276, 1992.

10. Itoh T, Kishi K, Tojo M, et al. Acinar cell carcinoma of the pancreas with elevated serum alpha-fetoprotein levels: a case report and a review of 28 cases reported in Japan. Gastroenterol Jpn 27: 785-791, 1992.

11. Ishizaki K, Koito $T$, Namieno $T$, et al. Acinar cell carcinoma of the pancreas: a rare case of an alpha-fetoprotein-producing cystic tumor. Eur J Radiol 21: 468-476, 1995.

12. Okamoto $\mathrm{K}$, Maesiro $\mathrm{K}$, Ikeda $\mathrm{S}$, et al. AFP producing acinar cell carcinoma of the pancreas in a 18-year-old man: a case report. Fukubu Gazou Shindan 15: 468-476, 1995 (in Japanese).

13. Fujiki T, Fuchino Y, Maki $T$, et al. A case of alpha-fetoproteinpositive advanced acinar cell carcinoma of the pancreas merkedly improved by intra-arterial infusion chemotherapy. J Jpn Surg Assoc 57: 2793-2797, 1996 (in Japanese, Abstract in English).
14. Sakon M, Osato $\mathrm{H}$, Kishimoto $\mathrm{S}$, et al. A patient with pancreatic acinar cell carcinoma, effectively treated by the infusion chemotherapy through hepatic artery using 5-FU, CDDP and MMC. Jpn J Cancer Chemother 23: 1614-1616, 1996 (in Japanese, Abstract in English).

15. Morii K, Okushin H, Yuasa S, et al. A case of alpha-fetoproteinproducing acinar cell carcinoma of the pancreas. Jpn J Cancer Clin 44: 915-920, 1998 (in Japanese, Abstract in English).

16. Shinagawa T, Tadokoro M, Yamagushi S. Cytomorphology of alpha fetoprotein-producing acinar cell carcinoma of the pancreas. St. Marianna Med J 27: 63-69, 1999.

17. Eriguchi N, Aoyagi S, Hara M, et al. Large acinar cell carcinoma of the pancreas in patient with elevated serum AFP level. J Hepatobiliary Pancreat Surg 7: 222-225, 2000.

18. Chen $\mathrm{CP}$, Chao $\mathrm{Y}, \mathrm{Li} \mathrm{CP}$, et al. Concurrent chemoradiation is effective in the treatment of alpha-fetoprotein-producing acinar cell carcinoma of the pancreas: report of a case. Pancreas 22: 326-329, 2001.

19. Akashi T, Funakoshi A, Sumii T, Iguchi H, Yonemasu H, Hattanda Y. Efficacy of chemotherapy in acinar cell carcinoma of the pancreas with elevated serum AFP level: case report. Suizo 16: 10-17, 2001 (in Japanese, abstract in English).

20. Yamauchi N, Ozeki Y, Sumi Y, et al. A case of alpha-fetoproteinproducing acinar cell carcinoma of the pancreas with portal vein obstruction. Tan to Sui 22: 1011-1016, 2001 (Abstract in Japanese).

21. Mori S, Kondoh S, Ryozawa $S$, et al. A case of AFP producing pancreatic acinar cell carcinoma diagnosed by EUS FNA and treated by intraarterial injection chemotherapy. Nisshoshi 101: 177-182, 2004 (in Japanese).

22. Mishima $Y$, Kobayashi $J$, Yamada $M$, et al. A case of AFPproducing pancreatic acinar cell carcinoma revealed by autopsy: usefullness of 5-FU/cisplatin chemotherapy to improve QOL. Matsue Shiritsu Byouin Igaku Zasshi 9: 47-53, 2005 (in Japanese, Abstract in English).

23. Okamura N, Kida M, Yanagisawa N, Ohbu M, Okayasu I. Pancreatic alpha fetoprotein-producing acinar cell carcinoma: an autopsy case report. Kitasato Med J 35: 27-29, 2005.

24. Lin YC, Lee PH, Yao YT, Hsiao JK, Sheu JC, Chen CH. Alphafetoprotein-producing pancreatic acinar cell carcinoma. J Formos Med Assoc 106: 669-672, 2007.

25. Kolb-van Harten P, Rosien U, Klöppel G, Layer P. Pancreatic acinar cell carcinoma with excessive alpha-fetoprotein expression. Pancreatology 7: 370-372, 2007.

26. Kawaguchi Y, Kono K, Mizukami Y, Hirai Y, Fujii H. A case of alpha-fetoprotein-producing acinar cell pancreatic carcinoma of which was indistinguishable from gastric cancer. J Jpn Surg Assoc 70: 2816-2822, 2009 (in Japanese, Abstract in English).

27. Fujii M, Sato H, Ogasawara T, et al. A case of liver metastasis of pancreatic acinar cell carcinoma treated with S-1 and intra-arterial CDDP combination therapy. Jpn J Cancer Chemother 37: 19871990, 2010 (in Japanese, Abstract in English).

28. Lee JH, Lee KG, Oh YH, et al. Acinar cell carcinoma of the pancreas: a report of two cases with long-term follow-up and a review of the literature. J Korean Surg Soc 79: 310-315, 2010.

29. Japan Pancreas Society. General Rules for the Study of Pancreatic Cancer. 5th ed. 2002.

30. Kitagami H, Kond S, Hirano S, Kawakami H, Egawa S, Tanaka M. Acinar cell carcinoma of the pancreas: clinical analysis of 115 patients from pancreatic cancer registry of Japan Pancreas Society. Pancreas 35: 42-46, 2007.

31. Craig JR, Peters RL, Edmonson HA, et al. Fibrolamellar carcinoma of the liver: a tumor of adolescents and young adults with distinctive clinic-pathologic features. Cancer 46: 372-379, 1980.

32. Edmondson HA. Differential diagnosis of tumors and tumor-like lesions of liver in infancy and childhood. Am J Dis Child 91: 168- 
186, 1956.

33. Collan Y, Hakkilouto A, Hastbacka J, et al. Ectopic liver. Ann Chir Gynaecol 67: 27-29, 1978.

34. Cubilla AL, Fitzgerald PJ. Morphological patterns of primary nonendocrine human pancreas carcinoma. Cancer Res 35: 22342248, 1975.

35. Morohoshi T, Held G, Kloppel G. Exocrine pancreatic tumor and their histological classification. A study based on 167 autopsy and 97 surgical cases. Histopathology 7: 645-661, 1983.

36. Klimstra DS, Heffess CS, Oertel JE, Rosai J. Acinar cell carcinoma of the pancreas. A clinicopathologic study of 28 cases. Am J Surg Pathol 16: 815-837, 1992.

37. Patrick JF, Joseph GF, Robin CW, et al. The value of diagnostic aids in detecting pancreas cancer. Cancer 41: 868-879, 1978.

38. Shimizu E, Kikuyama M, Hashimoto $M$, et al. A case of alphafetoprotein-producing pancreatic carcinoma. Review of 41 cases reported in Japan. Nisshoshi 93: 921-926, 1996 (in Japanese).

39. Ishikura $H$, Kirimoto $K$, Shamoto $M$, et al. Hepatoid adenocarcinoma of the stomach. An analysis of seven cases. Cancer 58: 119$126,1986$.
40. Kudo M, Takamine Y, Nakamura K, et al. Des-gamma-carboxy prothrombin (PIVKA-II) and alpha-fetoprotein-producing II c-type early gastric cancer. Am J Gastroenterol 87: 1859-1862, 1992.

41. Reddy JK, Rao MS, Qureshi SA, et al. Induction and origin of hepatocytes in rat pancreas. J Cell Biol 98: 2082-2090, 1984.

42. Ooi A, Nakanishi I, Sakamoto N, et al. Alpha-fetoprotein (AFP)producing gastric carcinoma. Is it hepatoid differentiation? Cancer 65: 1741-1747, 1990.

43. Hiraoka A, Kume M, Miyagawa M, et al. Diagnostic value of Sonazoid for hepatic metastasis: comparison with FDG PET/CT. Hepatogastroenterol 57: 1237-1240, 2010.

44. Hatanaka K, Kudo M, Minami Y, Maekawa K. Sonazoid-enhanced ultrasonography for diagnosis of hepatic malignancies: comparison with contrast-enhanced CT. Oncology 75: 42-47, 2008.

45. Kudo M, Hatanaka K, Chung H, Minami Y. A proposal of novel treatment-assist technique for hepatocellular carcinoma in the Sonazoid-enhanced ultrasonography: value of defect re-perfusion imaging. Kanzo 48: 299-301, 2007 (in Japanese, Abstract in English).

(C) 2012 The Japanese Society of Internal Medicine http://www.naika.or.jp/imindex.html 